\title{
MENINGKATKAN HASIL BELAJAR SISWA MELALUI MODEL PEMBELAJARAN KOOPERATIF TIPE MAKE A MATCH DI SMP NEGERI 7 KOTA TEBING TINGGI
}

\author{
Parulian Sijabat \\ Surel: bpkparlulinsijabat@gmail.com
}

\begin{abstract}
This study aims to determine student learning activities, and increase student learning outcomes by applying Cooperative Learning Type Make a Match models to integer operating material and class VII fractions as many as 38 students. This research is a classroom action research. In this study 3 cycles were used, consisting of 4 stages, namely planning, implementation, observation, and reflection. Obtained the value of mastery learning the initial test obtained 23.68\% (9 students) who completed. After teaching actions with the Cooperative Learning Type Make A match model, the results of observations of students in cycle I were $21 \%$ and the student learning outcomes of the first cycle were $42.10 \%$ (16 students) were completed. In the second cycle, the results of student observation were $45 \%$ and student learning outcomes tests were $55.26 \%$ (21 students) were completed. While in the third cycle the results of student observations were $76 \%$ and the student learning outcomes test was 86.84,\% (33 students) were completed.
\end{abstract}

Keywords: Learning Outcomes, Cooperative Learning, Make a Match.

\begin{abstract}
ABSTRAK
Penelitian ini bertujuan untuk mengetahui aktivitas belajar siswa, dan peningkatan hasil belajar siswa dengan menerapkan model pembelajaran Kooperatif Tipe Make a Match pada materi operasi bilangan bulat dan pecahan kelas VII sebanyak 38 siswa. Penelitian ini adalah penelitian tindakan kelas. Dalam penelitian ini digunakan 3 siklus, yang terdiri dari 4 tahap, yaitu perencanaan, pelaksanaan, observasi, dan refleksi. Didapat nilai ketuntasan belajar tes awal diperoleh $23,68 \%$ (9 siswa) yang tuntas. Setelah dilakukan tindakan pengajaran dengan model pembelajaran Kooperatif Tipe Make A match diperoleh hasil observasi siswa siklus I yaitu $21 \%$ dan tes hasil belajar siswa siklus I yaitu 42,10\% (16 siswa) yang tuntas. Pada siklus II diperoleh hasil Observasi siswa yaitu $45 \%$ dan tes hasil belajar siswa yaitu $55,26 \%$ (21 siswa) yang tuntas. Sedangkan pada siklus III diperoleh hasil observasi siswa yaitu $76 \%$ dan tes hasil belajar siswa yaitu $86,84, \%$ (33 siswa) yang tuntas.
\end{abstract}

Kata Kunci: Hasil Belajar, Pembelajaran Kooperatif, Make a Match

\section{PENDAHULUAN}

Pendidikan merupakan salah satu usaha untuk mencerdaskan kehidupan bangsa. Kemajuan suatu bangsa sangat ditentukan oleh kualitas sumber daya manusia. Kualitas sumber daya manusia sangat bergantung pada kualitas pendidikan. Pendidikan memegang peranan penting dalam pembangunan 
Parulian Sijabat : Meningkatkan Hasil Belajar Siswa ...

bangsa karena pendidikan sebagai akar pembangunan bangsa. Berhasilnya pembangunan dibidang pendidikan sangat berpengaruh terhadap pembangunan dibidang lainnya.

Pembelajaran terpusat pada guru sampai saat ini masih menemukan beberapa kelemahan. Kelemahan tersebut dapat dilihat pada saat berlangsungnya proses pembelajaran dikelas, interaksi siswa dengan guru atau siswa dengan siswa jarang terjadi. Siswa kurang terampil dalam menjawab pertanyaan atau bertanya tentang konsep yang diajarkan. Siswa kurang bisa bekerja dalam kelompok diskusi dan memecahkan masalah yang diberikan. Siswa cenderung belajar sendiri-sendiri.

$$
\text { Pembelajaran yang }
$$

disampaikan dengan ceramah membuaat siswa bosan, tidak bersemangat dikelas, kurang aktif dalam bertanya dan menjawab pertanyaan dan tidak berantusias saat berdiskusi kelompok dengan temannya. Dengan begitu siswa tidak dapat memahami konsep yang dipelajari dengan baik. Selain itu para guru terjebak dengan target kurikulum, sehingga kurang memperhatikan apakah siswa mengerti atau tidak materi yang diterimanya.

Berdasarkan latar belakang masalah yang telah diuraikan diatas, maka dapat diidentifikasi masalah yang relavan dengan penelitian antara lain : a. Siswa menganggap matematika sebagai mata pelajaran yang sulit.

b. Kurangnya Aktivitas belajar siswa.

c. Rendahnya Hasil belajar matematika siswa.

d. Kegiatan pembelajaran yang masih didominasi oleh guru.

Berdasarkan identifikasi
masalah, keterbatasan waktu dan
kemampuan penulis, maka penulis membatasi masalah yaitu: hasil belajar matematika siswa yang diajar dengan penerapan Model Pembelajaran Kooperatif Tipe Make a Match pada materi bilangan bulat dan pecahan dikelas VII SMP Negeri 7 Kota Tebing Tinggi.

Adapun yang menjadi tujuan penelitian ini adalah sebagai berikut:

a. Untuk mengetahui apakah melalui penerapan model pembelajaran kooperatif tipe make a match dapat meningkatkan hasil belajar matematika siswa pada materi bilangan bulat dan pecahan dikelas VII SMP Negeri 7 Kota Tebing Tinggi.

b. Untuk mengetahui apakah melalui penerapan model pembelajaran kooperatif tipe make a match dapat meningkatkan hasil belajar siswa dikelas VII SMP Negeri 7 Kota Tebing Tinggi.

\section{METODE PENELITIAN}

Dalam penelitian ini direncanakan hanya sampai 3 siklus saja, dan tiap siklus terdiri dari 2 kali 
pertemuan. Secara rinci, prosedur penelitian tindakan kelas ini dapat dijabarkan sebagai berikut:

\section{Siklus I}

Pada tahap perenaan tindakan ini, hal-hal yang dilakukan adalah :

a. Menyusun Rencana Pelaksanaan Pembelajaran (RPP) dengan menggunakan model pembelajaran kooperatif tipe make a match.

b. Membuat alat bantu untuk pelaksanaan pembelajaran berupa Lembar Aktivitas Siswa (LAS), dan buku untuk peneliti yang berisi skenario pembelajaran.

c. Mempersiapkan instrumen penelitian, yaitu: (a) tes untuk mengukur hasil belajar siswa, (2) lembar observasi untuk mengamati kegiatan (proses) belajar mengajar

d. Lembar observasi mengamati kegitan aktivitas siswa.

Setelah perencanaan tindakan I disusun dengan matang, maka tahap selanjutnya adalah pelaksanaan tindakan I. pada tahap ini, pemberian tindakan dilakukan dengan melakukan kegiatan belajar mengajar.

Observasi dilaksanakan pada saat berlangsungnya proses belajar mengajar dengan menggunakan pedoman observasi yang telah dipersiapkan untuk mengetahui aktivitas siswa dalam proses pembelajaran di kelas.
Selanjutnya, diadakan refleksi, seperti : Guru dan peneliti menganalisis dan mendiskusikan hasil pengamatan. Selanjutnya membuat suatu refleksi mana yang perlu dipertahankan dan mana yang perlu diperbaiki untuk siklus ke-2 nantinya.

\section{Siklus II dan III}

Pada prinsipnya semua kegiatan siklus II mirip dengan siklus I. Siklus II merupakan perbaikan pada siklus I, terutama didasarkan atas hasil refleksi pada siklus I, Setelah dilaksanakan siklus II dan hasil perbaikan yang diharapkan belum tercapai terhadap aktivitas dan hasil belajar yang telah ditetapkan peneliti, maka masih perlu dilanjutkan tindakan pada siklus III.

\section{HASIL PENELITIAN DAN PEMBAHASAN}

Subjek penelitian ini adalah seluruh siswa kelas VII-1 SMP Negeri 7 Kota Tebing Tinggi Tahun Pelajaran 2017/2018 yang berjumlah 38 siswa. Objek penelitian ini adalah pembelajaran matematika dengan penerapan model pembelajaran kooperatif tipe mak a match dalam meningkatkan aktivitas dan hasil belajar matematika siswa kelas VII SMP Negeri 7 Kota Tebing Tinggi Tahun Pelajaran 2017/2018.

Penelitian tindakan kelas ini dilaksanakan di SMP Negeri 7 jalan Haji Syech Beringin kecamatan Padang Hulu Kota Tebing Tinggi. Waktu penelitian dilakukan pada 
Parulian Sijabat : Meningkatkan Hasil Belajar Siswa ...

semester ganjil tahun ajaran 2017/2018.

Instrumen Penelitian dan

Teknik Pengumpulan Data yang pertama adalah lembar observasi siswa. Lembar observasi siswa adalah alat untuk mengamati dan menilai keaktifan siswa saat proses pembelajaran berlangsung. Lembar observasi ini disiapkan oleh peneliti dan pengisiannya berbentuk checklist $(\sqrt{ })$ dengan alternatif jawaban 1 dan 0 .

Tabel 1. Lembar Observasi Siswa

\begin{tabular}{|c|c|c|c|}
\hline No. & Aspek yang diamati & Kriteria Penilaian & $\begin{array}{c}\text { Skor } \\
\text { Perolehan }\end{array}$ \\
\hline \multirow[t]{2}{*}{1} & \multirow{2}{*}{$\begin{array}{l}\text { Mengemukakan ide dan } \\
\text { pendapat }\end{array}$} & Tidak mampu mengemukan pendapat & 0 \\
\hline & & Mampu mengemukakan pendapat & 1 \\
\hline \multirow[t]{2}{*}{2} & Bertanya & $\begin{array}{l}\text { Tidak mengajukan pertanyaan dan hanya } \\
\text { mengobrol dengan pasangannya }\end{array}$ & 0 \\
\hline & & Mengajukan pertanyaaan & 1 \\
\hline \multirow[t]{2}{*}{3} & Mendengar & Siswa asyik becanda dengan temannya & 0 \\
\hline & & Siswa mendengar temannya & 1 \\
\hline \multirow[t]{2}{*}{4} & Bekerja sama & tidak bekerja sama dengan kelompoknya & 0 \\
\hline & & Bekerja sama dengan kelompoknya & 1 \\
\hline \multirow[t]{2}{*}{5} & Mengerjakan LKS & Tidak mengerjakan soal & 0 \\
\hline & & $\begin{array}{l}\text { Mengerjakan soal dengan tekun dan } \\
\text { mandiri }\end{array}$ & 1 \\
\hline
\end{tabular}

Tes yang diberikan kepada siswa tes awal dan tes hasil belajar. Tes awal dilaksanakan sebelum pembelajaran dilakukan. Sedangkan tes hasil belajar diberikan setelah pembelajaran melalui model pembelajaran tipe make a match yang dilakukan oleh peneliti.

Analisis data dalam penelitian ini dilakukan melalui beberapa tahap, yaitu: proses reduksi data dilakukan dengan menyeleksi, menyederhanakan dan mentransformasikan data ringkasan atau uraian singkat dan pengelooan data kedalam pola yang lebih terarah; paparan data dilakukan dalam rangka mengorananisasi data yang merupakan kegiatan penyusunan informasi secara sistematik, untuk mendeskripsikan ketuntasan belajar siswa, yaitu data yang diperoleh dari tes awal dan tes akhir dari setiap siklus. Data yang digunakan untuk mengetahui skor hasil belajar siswa adalah menggunakan tes awal dan tes akhir siklus. Hasil pekerjaaan siswa pada tes tersebut masing-masing diberi skor sesuai dengan pedoman atau rubrik hasil belajar. 
Tabel 2. Pedoman Tingkat Penguasaan Tes Hasil Belajar

\begin{tabular}{c|c}
\hline Rentang Nilai & Kategori \\
\hline $90 \%-100 \%$ & $\begin{array}{c}\text { Sangat } \\
\text { tinggi }\end{array}$ \\
\hline $80 \%-89 \%$ & Tinggi \\
\hline $65 \%-79 \%$ & Sedang \\
\hline $55 \%-64 \%$ & Rendah \\
\hline $0 \%-54 \%$ & $\begin{array}{c}\text { Sangat } \\
\text { Rendah }\end{array}$ \\
\hline
\end{tabular}

Menarik Kesimpulan. Dalam menarik kesimpulan digunakan indikator penilaian sebagai berikut:

Menghitung Nilai Rata-Rata Siswa. Untuk menngetahui nilai ratarata siswa digunakan rumus:

Keterangan :

$$
\bar{X}=\frac{\sum X_{i}}{N}
$$

$\sum X_{i} \quad=$ Jumlah nilai siswa

$\mathrm{N} \quad=$ Jumlah Siswa

Arikunto, S. (2009:264)

Selanjutnya dapat juga diketahui apakah aktivitas secara klasikal telah tercapai, dilihat dari persentase siswa yang sudah aktif dalam belajar seperti yang dirumuskan sebagai berikut :

$$
\text { PAK }=\frac{\text { banyak siswa } \text { yang aktif }}{\text { banyak subjek penelitian }} \times 100 \%
$$

Keterangan:

PAK $=$ persentase ketuntasan

$$
\text { klasikal }
$$

Trianto. (2011:253)

Jadi, seorang siswa dikatakan sudah tuntas dalam belajar jika telah mencapai skor minimal $70 \%$ dan suatu kelas dikatakan aktif belajar jika dalam kelas tersebut terdapat
$75 \%$ siswa yang mencapai skor $70 \%$.

Persentase ketuntasan siswa Untuk mengetahui tuntasan belajar siswa secara individu (perorangan) dapat dihitung dengan persamaan :

$$
\mathrm{KB}=\frac{T}{T_{i}} \times 100 \%
$$

Keterangan :

KB : Ketuntasan Belajar

$\mathrm{T}$ : Jumlah skor yang diperoleh siswa

$\mathrm{T}_{i} \quad$ : Jumlah skor total

Dengan kriteria:

$0 \% \leq \mathrm{KB}<70 \% \quad$ : siswa

belum tuntas belajar

$70 \% \leq \mathrm{KB} \leq 100 \% \quad$ : siswa

telah tuntas belajar

Trianto (2011:241)

Secara individu seorang siswa dikatakan tuntas dalam belajar jika KB siswa tersebut telah mencapai minimal $70 \%$.

\section{HASIL PENELITIAN DAN PEMBAHASAN}

Untuk mengetahui pada permasalahan dilakukan pemberian tes awal kepada subjek penelitian. Hasil tes awal menunjukan masih banyak siswa yang tidak bisa menyelesaikan soal bilangan bulat dan pecahan.

Ketuntasan belajar matematika siswa pada pra siklus dapat jelas terlihat pada diagram dibawah ini. 


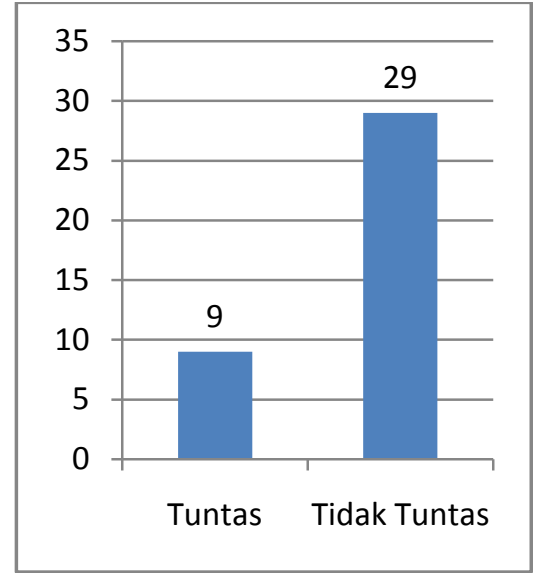

Diagram 1. Ketuntasan Belajar Siswa Pra Siklus

\section{Siklus I}

Peneliti dapat melaksanakan siklus I yang dimulai tanggal 19 juli 2017, Siklus I ini memiliki 5 jam pelajaran (@40 menit). Dua jam digunakan untuk pertemuan pertama. Dua jam esoknya untuk pertemuan kedua dan sisa satu jam untuk evaluasi kegiatan pembelajaran.

\section{Tabel 3. Pengamatan Aktivitas Siswa Berdasarkan Aspek Penilaian Aktivitas Siklus I}

\begin{tabular}{c|l|c}
\hline No & \multicolumn{1}{|c|}{ Aspek } & $\begin{array}{c}\text { Jumlah Siswa } \\
\text { yang } \\
\text { Melaksanakan }\end{array}$ \\
\hline 1 & Mengemukan ide & 22 Siswa \\
\hline 2 & Bertanya & 15 Siswa \\
\hline 3 & Mendengar & 18 Siswa \\
\hline 4 & Bekerja sama & 26 Siswa \\
\hline 5 & $\begin{array}{l}\text { Mengerjakan } \\
\text { LKS }\end{array}$ & 19 Siswa \\
\hline
\end{tabular}

Secara ringkas dapat kita lihat dari diagram berikut.

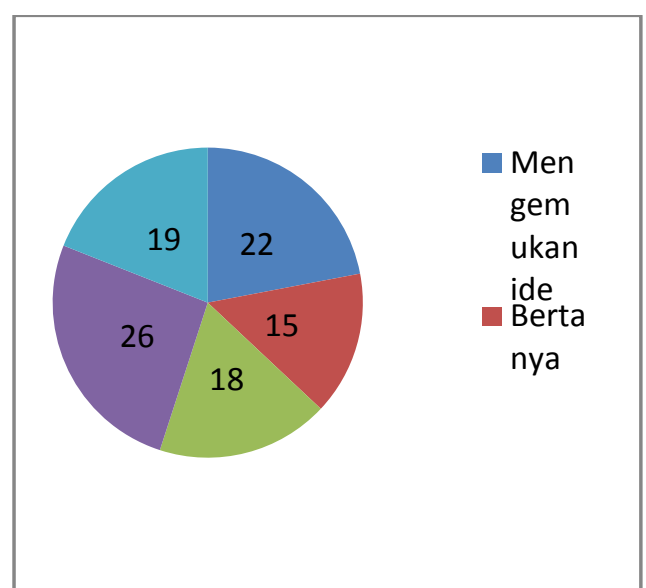

Daigram 2. Keaktifan Siswa Per Aspek

\section{Siklus II}

Setelah melaksanakan dan melihat hasil sebelumnya maka sekarang peneliti akan melanjutkan siklus II yang dimulai tanggal 27 juli 2017. Siklus II memiliki 5 jam pelajaran (@40 menit ). Dua jam pertama digunakan untuk pertemuan pertama. Dua jam esoknya untuk pertemuan kedua dan sisa satu jam untuk evaluasi kegiatan pembelajaran.

\section{SIMPULAN}

Berdasarkan uraian dari pembahasan pada penelitian ini, maka peneliti mengambil kesimpulan sebagai berikut:

a. Meningkatnya aktivitas belajar siswa kelas VII SMP Negeri 7 Kota Tebing Tinggi Tahun Ajaran 2017/2018 pada materi Operasi bilangan bulat dan pecahan pembelajaran kooperatif tipe make a match pada siklus I, siklus II dan siklus III. Rata-rata Aktivitas Kelas 
pada siklus I sebesar $21 \%$ meningkat menjadi $45 \%$ pada siklus II dan meningkat menjadi $76 \%$ pada siklus III.

b. Meningkatnya hasil belajar siswa kelas VII SMP Negeri 7 Kota Tebing Tinggi Tahun Ajaran 2017-2018 pada materi Operasi bilangan bulat dan pecahan model pembelajaran kooperatif tipe make a match pada siklus I, siklus II dan siklus III. Terjadi peningkatan pada tes hasil belajar siswa siklus I dengan ketuntasan yang dicapai pada siklus I sebesar $42 \%$, pada siklus II sebesar $55 \%$, dan $87 \%$ pada siklus III.

\section{DAFTAR RUJUKAN}

Abdurrahman, Muliyono. 2009. Pendidikan Bagi Anak Berkesulitan Belajar. Jakarta: Rineka Cipta

Agus, Nuniek Avianti. 2007. Mudah Belajar Matematika 2: Untuk kelas VIII Sekolah Menengah Pertamal Madrasyah Tsanawiyah. Jakarta: Pusat Perbukuan Departemen Pendidikan Nasional.

Arikunto, Suharsimin. 2009. Penelitian Tindakan Kelas. Jakarta: Bumi Aksara.

Dimyanti dan Mudjiono. 2009. Belajar dan Pembelajaran. Jakarta: Rineka Cipta.

Hudojo, Herman. 2005. Pengembangan Kurikulum Dan Pembelajaran
Matematika. Malang: Ikip Malang.

Isjoni. 2009. Pembelajaran Kooperatif. Yogyakarta: Pustaka Pelajar.

Istarani. 2011. 58 Model Pembelajran Inovatif. Medan: Media Persada.

Kunandar. 2007. Guru Profesional. Jakarta: Raja Grafindo Persada. Kunandar. 2010. Langkah Mudah Penelitian Tindakan Kelas Sebagai Pengembangan Profesi guru. Jakarta: Raja Grafindo Persada.

Muslich, Masnur. 2009. Melaksanakan Penelitian Tindakan Kelas Itu Mudah. Jakarta: Bumi aksara

Rohani, Ahmad. 2004. Pengolalan Pembelajaran Edisi Refisi. Jakarta: Rineka Cipta

Sinaga, B, dkk. 2013. Matematika SMP IMTS Kelas VII Kurikulum 2013. Jakarta: Politeknik Negeri Media Kreatif

Slameto. 2010. Belajar Dan FaktorFaktor Yang Mempengaruhinya. Jakarta: Rineka Cipta

Suprijono, Agus. 2009. Cooperative Learning Teori Dan Aplikasi PAIKEM. Yogyakarta: Pustaka Pelajar.

Trianto. 2009. Mendesain Model Pembelajaran Inovatif Kontenporer. Jakarta: Bumi Aksara. 